\title{
THE FLORENTINE ARMY IN THE AGE OF THE COMPANIES OF ADVENTURE
}

\section{EL EJÉRCITO DE FLORENCIA EN LA ÉPOCA DE LAS COMPAÑÍAS DE MERCENARIOS}

William Caferro

Vanderbilt University

\begin{abstract}
The essay explores the recruitment and composition of the Florentine army in the fourteenth century. It stresses the importance of native troops and continuity of service among mercenaries in an era associated with free companies and organizational chaos. The Florentine army was, in contrast to the current literature, not an ad hoc and temporary entity but the product of careful consideration and coordination.
\end{abstract}

Keywords: Companies of Adventure, Continuity, Native Infantry, Rural Lords, Lance Unit.

\section{RESUMEN}

Este artículo explora el reclutamiento y composición del ejército florentino en el siglo XIV. Subraya la importancia del uso de tropas nativas y de la continuidad del servicio entre los mercenarios, en una era asociada a las compañías "libres" de mercenarios y al caos organizativo. El ejército florentino fue, en contraste con la literatura actual, no una entidad temporal y creada ad hoc para un momento concreto, sino el producto de una cuidadosa preparación y coordinación.

Palabras clave: compañías mercenarias, continuidad, infantería nativa, señores rurales, lanza. 


\section{RESUM}

\section{L'exèrcit de Florència al temps de les companyies de mercenaris}

Aquest article explora el reclutament i composició de l'exèrcit florentí al segle XIV. Subratlla la importància de l'ús de tropes natives i de la continuïtat del servei entre els mercenaris, en una era associada a les companyies "lliures" de mercenaris i al caos organitzatiu. L'exèrcit florentí va ser, en contrast amb la literatura actual, no una entitat temporal i creada ad hoc per a un moment concret, sinó el producte d'una acurada preparació i coordinació.

Paraules clau: companyies mercenàries, continuïtat, infanteria nativa, senyors rurals, llança. 
The recruitment and composition of armies in fourteenth century ltaly are among the most vexing and misunderstood aspects of medieval warfare. Such scholarship as there has been emphasizes the reliance of states on mercenary troops and the advent in the trecento of compagnie di venturacompanies of adventure-, bands of mercenaries from ltaly and elsewhere in Europe, who overwhelmed the native component of armies and undertook raids in times of peace. The companies have served as the symbol of the loss of communal fighting spirit and with it the moral degeneracy of Italian states. What has been forgotten in this construct is the realities of warfare and the actual nature of Italian armies. How were soldiers recruited, what did armies look like and how were they deployed in the field?

The current scholarly consensus speaks of a "devolution" of military organization. In the thirteenth century, states relied primarily on native forces, reflecting a vigorous "communal martial spirit." In the fourteenth century, states came to rely more on mercenaries, arrayed often in pre-formed bands. By the fifteenth century, the bands became replaced by powerful individual condottieri, who in several well-known cases took over the states they served. 'This last phase is a main theme of Jacob Burckhardt's seminal Civilization of the Renaissance in Italy. Burckhardt saw in the condottieri the type of calculated self-interest and "unbridled egotism" that was representative of the Renaissance as a whole.

1 RICOTTI, E. (1844): Storia delle compagnie di ventura in Italia, vol. 2. Turin, Unione Ed.; CANESTRINI, G. (1851): "Documenti per servire della milizia italiana del secolo XIII al XVI". Archivio Storico Italiano, ser. 1, 15, XI- CXXVI; SCHÄFER, K. H. (1911): Deutsche Ritter und Edelknechte in Italien wahrend des 14. Jahrhunderts, vol. 1. Paderborn, Paderborn Schöningh; MALLETT, M. (1974): Mercenaries and Their Masters: warfare in Renaissance Italy. Totowa, NJ, Rowman and Littlefield. The scholarly terms of discussion are outlined in CAFERRO, W. (1998): Mercenary Companies and the Decline of Siena. Baltimore, Johns Hopkins, pp. XIV-XV, 1-14; GRILLO, P. (2008): Cavalieri e popoli in armi: Le istitutioni military nell'Italia medieval. Bari, Editori Laterza. 
This portrait of Italian warfare bears the stamp of Niccolò Machiavelli, who depicted "lazy" "useless" mercenaries as the ruination of Italy and blamed them and the states who hired them for the foreign subjugation of the peninsula in the fifteenth century. The present essay examines the Florentine army during the era of the companies of adventure. The period was chosen because the Florentine army has been judged by scholars as "retrograde" and "backward" even with respect its counterparts in Venice and Milan. Florence stands accused not only of relying on mercenaries, but of hiring men on short-term contracts and dismissing them wholescale from service at the end of "the campaigning season." Florence did this while Venice and Milan began hiring its mercenaries on longer-term contracts, promoting continuity in the ranks, and more generally encouraging permanent forces that remained under contract even in times of peace. ${ }^{2}$ Florentine forces were ad hoc.

The dated scholarly consensus requires revision. Indeed, close archival study reveals (unsurprisingly) that Florence devoted much attention to its army. It relied on mercenaries, but it chose the men with care and maintained longterm relationships with them despite short-term contracts. Florentine officials recruited mercenaries alongside rural feudal lords, who played an important and often overlooked role in warfare. In addition, Florence maintained a substantial infantry force, much of which was recruited from its contado and subject communes and was far more professionalized than has been portrayed. Finally, any evaluation of Florence's army must be understood in terms of the city-leagues or taglie that the city joined during this era. The leagues were enacted by participants (often neighboring cities) to provide a share (taglia) of troops for joint armies for the purposes of mutual protection in times of external threat. They were so frequent that it is difficult to find a single year for which Florence was not involved in one. Thus, it was the case, to paraphrase Daniel Waley for the first years of the trecento, that the Florentine army was as much an expression of "regional military policy" as it was an expression of the city's own civic power.

\section{I}

Discussions about the Florentine army usually begin in the year 1250 , when the city issued a code governing its composition. The code was the work of Florence's first popular government, the so-called primo popolo. Giuseppe

2 CAFERRO, W. (2008): "Continuity, Long-Term Service and Permanent Forces: A Reassessment of the Florentine Army in the Fourteenth Century". The Journal of Modern History, n ${ }^{\circ} 80, \mathrm{pp}$. 219-220. 
Canestrini published the document in the nineteenth century and stressed how it reflected the "native nature" of the Florentine army. ${ }^{3}$ It revealed a Florentine army arranged in twenty compagnie recruited from the popolo of the city and leghe recruited from 96 pievi in the contado. A pieve consisted of a single town or several communities. All compagnie and leghe were led by captains, whose brigades were variable in size. Men between the ages of 15 and 70 who resided in the city (cittadini) and contado (contadini) were eligible to serve in the army. Magnates and Ghibellines (often the same) were expressly forbidden from participating because their loyalties were suspect. ${ }^{4}$ In times of civic unrest, the army assumed police functions. It protected government buildings and arrested exiles and other malfatori, who caused trouble. In times of war, the compagnie formed the cavalry core of the army. The vanguard of the army consisted of the so-called feditori, the striking force, followed by the infantry, who stood behind the cavalry. The route of armies out of Florence to the battlefield was carefully planned in conjunction with astrologers. Local shops were closed, city bells rang and the carroccio, a wheeled cart that was the symbol of the city, went forward under heavy guard.

Daniel Waley has questioned the degree to which the military code of 1250 reflected the true nature of Florentine forces. Waley sees it as part of a general institutional reorganization that involved also the transfer of the internal police duties of the force to civic officials. Nevertheless, the importance of native troops in the Florentine army is clear. The famous libro di Montaperti gives important detail about an actual Florentine army deployed in the eponymous battle of 1260. Native Florentine cavalry numbered nearly 1400 men. The mercenary cavalry consisted of only 200 men, recruited primarily from the nearby Emilia and Romagna regions, just north of Florence. The infantry, believed to be more than 16,000 men, was recruited from the Florentine contado. ${ }^{5}$ Waley saw little trace of the deployment of urban compagnie in the battle and in subsequent armies.

4 NALDINI, L. (1920): "La 'tallia militum societatis tallie Tuscie' nella seconda metà del sec. XIII". Archivio Storico Italiano, LXXVIII, pp. 78-79.

5 WALEY, D. (1968): "The Army of the Florentine Republic from the Twelfth to the Fourteenth Century". RUBINSTEIN, N. (ed.), Florentine Studies. Evanston, Northwestern University Press, pp. 76-78. 
The army at Montaperti was nevertheless an overwhelmingly Florentine one, and its calamitous defeat at the hands of Siena and its Ghibelline allies, who relied on German mercenary cavalrymen, gave impetus to change. After the battle, Florence began systematically to recruit mercenaries. This was aided by involvement in a series of Guelf Tuscan leagues, headed by the king of France's brother, Charles of Anjou, who became ruler of Naples and the kingdom of Sicily in 1266. Participation brought numerous French and Provencal mercenaries into Florentine service, including the distinguished captain Amauri of Narbonne.

For all the discussion of Montaperti as a turning point in Florentine military organization, the limited evidence also suggests that Florence continued to rely on native troops through the end of the thirteenth and beginning of the fourteenth century. A careful analysis by Cesare Paoli of the Florentine army assembled to fight against neighboring Pistoia in May of 1302 shows that the force consisted almost wholly of native cavalry and infantry. ${ }^{6}$ The composition of the army is listed in table 1.

Table 1. Composition of the Florentine Army, 1302

497 Cavalrymen from the city

117 Crossbowmen from outside the city

644 Crossbowmen and shield bearers from Florence

3,961 Infantrymen from the contado and Florentine state

1058 Non-Florentine infantrymen

972 Guastatori (Destroyers)

The native element was clearly significant, and the army also had a considerable number of infantrymen. The latter owed to the fact that the campaign against Pistoia involved besieging the city, which required infantrymen as well as contingents of guastatori or destroyers, who set fires, dug ditches and mined below fortifications. The guastatori were often country rustics

6 PAOLI, C. (1867): "Rendiconto e approvazione di spese occorse nell'esercito fiorentine conto Pistoia nel Maggio MCCCII". Archivio Storico Italiano, ser. 3 vol. 6, p. 7. 
with little training. But their contribution to war, especially during sieges, was important. ${ }^{7}$

Paoli suggests that the army of 1302 also contained mercenaries who do not appear on the Florentine payroll, but most likely were supplied to the city by its allies. The judgment underscores a basic problem in evaluating armies of this and all periods: it is difficult to isolate a precise "Florentine army" from the bands of auxiliaries and additional troops sent by allies. Likewise, Florence's participation in city-leagues (taglie), which required each adherent to provide a share of the troops for a joint army, further obscures the line between what was specifically Florentine and what was not. The leagues were joined more frequently after Montaperti and the arrival in Italy of Charles of Anjou. Charles became the guiding force behind the Guelf cause and a champion of leagues, which continued after he died in $1285 . .^{8}$ In his pioneering essay on the league (taglia) of 1281, Lamberto Naldini argued that the alliance, and those that immediately followed, gave impetus to the formation of a regional Tuscan economy, and, inasmuch participants recruited professional soldiers who stayed on the payroll over the long run, encouraged the dependence on mercenaries, which came at the expense of the "old feudal class" of native soldiers. " Daniel Waley has claimed that the leagues were so important to Florentine military organization that the local army can only be understood in regional "Guelf" rather civic terms.

Waley is nevertheless too quick to dismiss the significance of the "Guelf" political label, just as Naldini is too hasty to announce the end of the feudal class. Florentine armies of the early trecento and subsequent years always contained soldiers from the feudal class of rural magnates who inhabited the Italian countryside. Moreover, however amorphous the label Guelf may appear to modern scholars, it had real meaning in its historical context. All Italian soldiers hired by Florence were specifically required to be "faithful Guelfs," a stipulation written into their contracts. In addition, it is important to stress that Italian military and political history on the peninsula was not driven solely by the actions of major states such as Florence, Venice, Pisa,

7 BIANCHI, S. A. (1995): "Gli eserciti delle signorie venete del Trecento fra continuità e trasformazione". CASTAGNETTI, A. and VARANINI, G.M. (eds.), II Veneto nel medioevo. Verona, Banca Popolare di Verona, p. 176.

8 WALEY, "The Army of the Florentine Republic", p. 80.

9 NALDINI, "La 'tallia militum societatis tallie Tuscie'", p. 77. 
Genoa and others. There were, throughout Italy, many independent feudatories that pursued their own interests, alternately siding with their neighbors and against them. They chose sides in Guelf and Ghibelline rivalries and when they were not themselves at war, they hired themselves out to fight wars for others. The captains of the Guelf leagues included independent rural lords such as Ranuccio Farnese, from southern Tuscany, and Aghinolfo of Romena, from the mountains in the Casentino north of Florence. Meanwhile, Florence routinely recruited horsemen from Umbria, the Marches of Ancona and the Romagna. The service of members of lordly clans of these regions was remarkably enduring. The counts of Sarteanno in southern Tuscany, for example, worked both for and against Florence throughout the thirteenth and fourteenth century, as did members of the Tarlati clan from near Arezzo. The image of local lords turned into the great condottiere famously outlined by Jacob Burckhardt for the fiffeenth century had its roots in the fourteenth.

Florence's wars against Castruccio Castracane, the powerful lord of Lucca, in the 1320s have been viewed by scholars as a point of no return in the transformation of communal armies. Castruccio posed a grave threat to Florence and the battles against him were especially bitter and protracted. Castruccio's military might owed in large part to the support of the German emperor Ludwig of Bavaria, who supplied Castruccio with German mercenaries for his cavalry. The men were effective at Altopascio in 1325, where Florence suffered a stunning defeat. After Altopascio, Florence began to recruit German cavalrymen in significant numbers. They replaced the largely French and Catalan mercenaries that the city had employed during the years that Charles of Anjou was active in Italy. They had been ineffective and untrustworthy at Altopascio. ${ }^{10}$

The aftermath of the battle of Altopascio represented the start of the so-called era of the companies of adventure (compagnie di ventura), who would play an important part in political and military affairs on the Italian peninsula until the end of the trecento. In 1337 Florentine issued a new code governing its army and reordering the office of the condotta that hired troops. The code coincided with the start of yet another war, this time against the della Scala lords of Verona. Florence sought an alliance with Venice, whose interests were similarly threatened by the expansionist Scala state. The terms

10 WALEY: "The Army of the Florentine Republic", p. 106; CANESTRINI, "Documenti", p. xxVI. 
were generally unfavorable to the Florentines, who sent money north to help the Venetians repel the Scala. But Venice did little to help Florence with the Scala threat in Tuscany, which centered on the nearby city of Lucca.

C. C. Bayley interpreted the terms of the military code of 1337 as evidence of the "infiltration" of the "mercenary element" into Florentine armies. ${ }^{11}$ The point is, however, overstated. The code, which was the work of a committee of prominent citizens (Francesco Bilioti, Filippo Duccio Magalotti, Tommaso Dietiauti, Luca Gerini delle Strozzi, Benincasa Falchi and Aldobrando Lapi Tanaglie), encouraged the use of mercenaries, notably ultramontane soldiers (those from beyond the Alps), but native elements also remained. ${ }^{12}$ City officials were permitted to hire 800 cavalrymen and 1000 infantrymen directly through the office of the condotta, but all additional hires needed the consent of the priori, gonfalonieri and twelve buonuomini, who formed the executive branch of the government. ${ }^{13}$ The hire of Florentine citizens, contadini and Italian soldiers required the specific approval of these same officials. No more than fifteen Italian cavalrymen were allowed to serve in units of twenty to fifty men. Ultramontane cavalry units consisted of 20 men. Soldiers received their pay at the beginning of each month. Foreign soldiers required a mallevedore to serve as surety for their service in case of fraud. All cavalry captains had to maintain a horse worth 50 florins, while cavalrymen needed to have horses worth 30 florins.

The code also contained important guidelines on how soldiers had to arm themselves for war and the penalties for failing to pass musted. Cavalry captains supplied their own horse, armor and weapons. These included a breastplate with iron sleeves, a steel helmet, a shield, lance and dagger. Failure to pass muster was punished by a fine. To this end, officials carefully listed the names of the troops and their equiptment. Muster was held two days after the payment of wages. Fines were deducted directly from soldiers' pay.

Florence arranged its armies primarily in banner units, described in the code as consisting of twenty to twenty-five men. This included both cavalry and infantry units, the basic divisions of the army. Florence hired men on contracts (condotte) ranging from four to six months long. The code says explicitly that troops could not serve for more than six months without additional approval. C. C. Bayley says that Florence's preference for short-term

11 BAYLEY, C. C. (1961): War and Society in Renaissance Florence: The De Militia of Leonardo Bruni. Toronto, University of Toronto Press, p. 15.

12 CANESTRINI, "Documenti", p. 498.

13 CANESTRINI, “Documenti”, pp. 498, 501-502. 
contracts was based on the "fading assumption" that "war was brief."14 But this is not true. Florentine public officials chose short term contracts to avoid nepotism and circulate new people into these important jobs. This was true of civic jobs as well as military ones. The priori of the Signoria, the chief executives of the city, served two-month terms, members of the advisory councils, the twelve buonuomini and sixteen gonfalonieri, held office for three and four months, respectively. The podestà, who helped maintain internal peace and defend against external enemies, served on a six-month contract. In the case of the army, the short-term contracts were related to quality and control, allowing city officials to routinely reassess its force and dismiss those soldiers who were lacking.

Further proof of this is the evidence that those soldiers who served well were often rehired, despite their short-term contracts. Some men worked for Florence for long periods of time, including the restless and so-called "faithless" mercenaries. The German captain Gottfried Roher was, for example, hired by Florence in 1334 on a six-month contract. He remained in Florentine employ on similar contracts without interruption until 1354. In that year, he joined the famous free company of the Provencal adventurer Fra Moriale, which extorted a large bribe from Florence and other cities.

Throughout the fourteenth century, Florence often rehired the same mercenary cavalry captains. The length of service stipulated in their contracts did not determine how long they actually served the city. The Italian mercenary captain Nino di Dini degli Obizzi, a Guelf exile of Lucca, worked for Florence for a full sixteen years from 1347 to 1362. The German captains Edvard Bingher, Hans Dornich, and Heinrich Paer worked for Florence for at least a decade, always on four- to six-month contracts. Wilhelm Belmont stayed in the city's employ for twelve consecutive years from 1343 to $1354 .{ }^{15}$

Germans were the most numerous of the mercenaries in Florentine employ through the middle of the trecento. But the trend toward long-term employment on short-term contracts cut across national lines. Hungarian mercenaries, whose numbers, like those of the English, were small, also worked for Florence for extended periods. Georgio Gregori, a Hungarian horseman, was on the payroll for thirteen consecutive years, on four-month contracts.

14 BAYLEY, War and Society in Renaissance Florence, p. 9.

15 Archivio di Stato di Firenze (ASF), camarlinghi uscita, 80, fols. 1r-32r compared with Provvisioni, registri, 26, fol. 149v; Miscellanea Repubblicana, 119, fols. $11 \mathrm{r}-12 \mathrm{v}, 35 \mathrm{r}, 44 \mathrm{r}$; 120, fols. 2r, 12v, 18r; camarlinghi uscita, 6, fols. 1r-17v; 7, fol. 176r; scrivano di camera uscita, 1 , fols. 17r-25r. 
Another Hungarian, Bachone di Giovanni, served for eleven consecutive years, from 1360 to 1370, also on four-month contracts. The English captain Oschino Archer worked for Florence for seven consecutive years. Johnny Liverpool served the city for eight consecutive years on four, five and six-month contracts.

The career of the German captain Burchardt da Toro is especially noteworthy. He appears to have been hired by Florence in 1341, for the army sent against Pisa. He remained in Florentine employ through the rest of the decade and was part of the feditori contingent that took on the Ubaldini clan in 1350. A year later, when the Milanese threatened the Florentine state, Burchardt was put in charge of all Florentine forces. His army guarded the northern passes into the Florentine state in the Mugello and took part in the heroic defense of the town of Scarperia, for which he received bonus pay. He was subsequently used as an ambassador and appears to have integrated himself into Florentine society.

The evidence makes clear that at the same time that Florence began to rely more on mercenaries, particularly foreign born ones, it also attempted to maintain a continuity of personnel. The city built its forces around a core of seasoned professionals. The portrait contradicts the current scholarly view that stresses the ad hoc and backward nature of Florentine forces. But there is no reason to assume that Florence, even in the era of mercenary companies, did not give careful thought to their army, which was so frequently in the field.

Indeed, a careful examination of Florentine budgets shows that of the forty mercenary captains listed as serving in the army against Milan in May/June 1351, twenty-two (55 percent) had previously worked for Florence, several for nearly a decade. The leadership of Florentine forces in September/ October 1369, on the eve of the battle of Cascina, consisted of ninety-four mercenary captains, sixty-three of whom (67 percent) had already worked for Florence for at least four years. The army deployed to fight the papacy in September/October 1376 contained forty-five mercenary captains, of whom thirty-three (73 percent) had worked previously for Florence, most for at least five years. ${ }^{16}$

A more difficult task is assessing the role of infantry in Florentine armies. As we have seen, the number of such men was large in the late thirteenth and early fourteenth century. Nevertheless, the chronicle sources, which often give precise (albeit suspect) figures for the cavalry, frequently describe 
the infantry as a "mass of men." The generic rendering is likely related to the lack of status of the men. But even so, we must take care not to make rash judgments. Indeed, Florentine budgets (beginning from 1343) suggest that Florence took care assembling its contingents of crossbowmen, shield bearers and mixed bands that contained both. The budgets provide the provenience of the captains of these units and show that many, like their predecessors of the earlier years, came from the Florentine contado, distretto and subject lands. The wealth of documents that survive for Florence's conflict with the Ubaldini clan in 1350 show that the army sent by the city to the Apennine mountains in the Mugello region was composed of infantry captains from that area, and from mountain villages in the Garfagnana near Lucca and the mountains near above Pistoia. Florentine officials, in short, consciously recruited men adapted to the type of warfare (in the mountains) that it intended to wage. ${ }^{17}$

Similarly, there is evidence among infantrymen of long-term service despite short term contracts. The shield bearer captain Francesco Bartoli from Florence, known by the nickname "Malamama" (or "bad mother"), began working for communal armies in 1349 and continued to work for Florence until 1353. He appears again in the records from 1359 to 1370 . The infantry captain Ottolino Casoli from Prato worked for the city continuously from 1362 to 1378, while luntino Giuntini from Sarzana worked as a captain of crossbowmen units from 1365 to $1379 .{ }^{18}$

There are many additional examples and much more work needs to be done and can be done with close inspection of extant budgets. But the evidence suggests that even the infantry, whose value is traditionally undervalued by scholars, was arranged with care and there was a measure of continuity in the ranks. The notion is not far-fetched, as the geography of Tuscany, with its many hills, necessitated siege rather than war of maneuver in the field.

It is important to note that the continuity in Florentine armies occurred over diverse communal regimes and numerous wars. Gottfried Roher fought against the Scala at Lucca in 1338, against Pisa in 1341 and against Milan from 1351-1353. In the meantime, he survived the shift of government from the popolo to the duke of Athens in 1343 and the expulsion of the duke shortly thereafter.

17 CAFERRO, W. (2013): "Petrarch's War: Florentine Wages at the Time of the Black Death". Speculum, n 88/1, pp. 144-165.

18 CAFERRO, "Continuity, Long-Term Service and Permanent Forces", pp. 233-234. 


\section{II}

The example of the Florentine army that fought against the Pisans in 1341 reveals the increased influence of mercenary soldiers. The main striking force was now made up of 2,000 mercenaries, captained by an Italian knight, Matteo de Pontecarali. The citizen cavalry numbered no more than 40 men, although it included members of the leading families of the city. The lack of a native element caught the attention of the chronicler Giovanni Villani, who questioned the wisdom of city officials for putting the fate of the commune in the hands of outsiders. The complaint must be understood, however, in terms of Villani's bitterness at the eventual defeat of the Florentine force. ${ }^{19}$ Villani's main objection was that the army had too many knights in it, such that the captain general had difficulty coordinating the men, who did not listen to him. Nevertheless, the army was arrayed in much the same way that it was when it took the field in 1337. The basic fighting unit remained the "banner," consisting of twenty to twenty-five men. It was used both by the cavalry and infantry. The cavalry striking force or feditori was, as in the past, at the vanguard of the army, with the infantry behind it. Important and basic changes were nevertheless beginning to occur in Florentine armies. A turning point for Florence and all of Italy occurred with the arrival of the English White Company on the peninsula in 1361. The famous Company crossed the Alps from France to participate in war in the Piedmont region in the employ of the Marquis of Montferrat. The band, made up primarily of Englishmen but commanded by a German, created a sensation, owing to its cruel efficiency in battle. In the summer of 1363, with the help of the Visconti of Milan, the band took up employ with Pisa, which was at war with Florence. During the transfer, the band's most notable member, John Hawkwood, took over leadership of the company and with it the Pisan army. Under his command, Pisan forces gained the momentum in a war that had been a tedious and all-too-familiar contest of maneuver since it began in 1362. Florence responded to the White Company by hiring large bands of the German mercenaries, including those led by the southern German nobles Johann and Rudolf Hapsburg.

The conflict marked the start of a new era in the reliance on mercenaries for Florence. The city now routinely sought the service of large organized companies of men rather than only small units. It is important to stress this point, which suggests that the reliance on "companies" of mercenary men 
was not the result of a natural evolution or, better, "devolution" of mercenary service, as scholars have long suggested, but more the result of happenstance and the concurrence of the Hundred Years War in France, which created such bands. Hawkwood and the Pisan army penetrated to the walls of Florence in 1364. The city saved itself by bribing the English company, as well as a German band captained by another notable mercenary, Hannekin Baumgarten. Hawkwood gained a reputation for honesty by being among the few soldiers who turned down the Florentines. He remained at the head of Pisan forces.

After the war, Florence recruited large bands of mercenaries and frequently sought the services of John Hawkwood, who had emerged as the best commander of his generation. It is important to note, however, that Florence continued to hire small bands of mercenaries and to build its army from a small cadre of faithful, battle proven soldiers. It also continued to hire rural lords and exiles from enemy cities in its armies. They provided vital reconnaissance, regardless of their qualities as men at arms.

Changes in the organization of the Florentine army come into fuller view when the city fought its next major opponent, Milan, in 1369. As happened in 1337, Florentine officials issued a code governing its army at the outset of conflict. The code is notable for its stark difference from the earlier one. It included specific rules regarding a wide array of mercenary cavalrymen, including those of English, German, Burgundian, Italian and Hungarian background. The code of 1337 speaks only a generic terms of "mercenaries."

A close reading of the code of 1369 makes clear the primacy of English mercenaries above all others. They were the most desirable soldiers. Their contingents included the famed longbow archers that had performed so well in France. But the overall number of archers remained small in Italy, and they do not appear to have had a major impact in battles. The effect of the English is most apparent in the change from the use of banners as the basic cavalry unit to lances. The lance consisted of three men: a knight, a squire and a page, each with his own mount. The page was typically a young man or apprentice who rode a pony. ${ }^{20}$ According to the Florentine chronicler Filippo Villani, "it was the English who introduced this formation into Italy. ${ }^{21}$ The Florentine infantry does not appear to have undergone a

20 CAFERRO, W, (2006): John Hawkwood: An English Mercenary in Fourteenth Century Italy. Baltimore, Johns Hopkins, p. 88.

21 VILLANI, Filippo (1980): Cronica di Matteo e Filippo Villani, vol. 5. Rome, Multigrafica, p. 258; CAFERRO, John Hawkwood, p. 88. 
similar transformation. The banner remained the standard unit among crossbowmen and shield bearers.

Much has been written about the lance. Geoffrey Chaucer's "worthy knight" in the prologue to the Canterbury Tales belonged to a lance unit. In the battles of the Hundred Years War, the formation has been seen as facilitating the dismounting of cavalry that contributed to England's great victories against French armies at Crecy and Poitiers. In Italy, the lance became the standard unit of organization for cavalry throughout the peninsula. The historian Stephan Seltzer has traced the shift from banners to lances in the armies of Perugia, Venice and the papacy in 1367/68 and in the armies of Milan and Modena in 1370. ${ }^{22}$ Thus whether inspired directly by the English or by the actions of other states, Florence's change to lances coincided with broader military developments.

The precise meaning of the shift to lances is nevertheless not entirely clear. Was the change primarily an administrative one or did it have tactical military meaning in its Italian context? Stephan Selzer emphasizes the latter, arguing that the lance encouraged in Italy the type of "dismounting" technique used by the English cavalry in the Hundred Years War. ${ }^{23}$ Paolo Grillo has more recently affirmed Selzer's judgment, seeing the use of the lance as evidence of English influence on the methods of Italian war. ${ }^{24}$ The difficulty with the interpretation, however, is that it is not entirely clear how the banner unit that preceded the lance was deployed in the field, nor is it clear how many horses a captain had and how many ancillary personnel. The evidence relating to military practice in the field suggests that Florence rarely confronted an opponent directly, as occurred up north at the battles of Crecy and Poitiers.

In any case, the shift by Florence to lances in 1369 appears to have occurred by degrees, and prior to Florence's active engagement with an enemy. In December 1367, the city hired its first lance unit. On 8 December 1367, after two years of service at the head of a banner unit of cavalrymen, the English soldier Oschino Archer shifted to command a single "lance" unit. On that same day, Florence hired three additional Englishmen, William Bocoste, Edward Bertum and John of London, each at the head of a lance unit. ${ }^{25}$ Two days later, Florence hired fourteen more English captains

22 SELZER, S. (2001): Deutsche Söldner im Italien des Trecento. Tubingen, Niemeyer, pp. 56-57; CAFERRO, John Hawkwood, p. 88.

23 SELZER, Deutsche Söldner im Italien des Trecento, pp. 56-57.

24 GRILLO, Cavalieri e popoli in armi, p. 154.

25 ASF, Scrivano di camera uscita, 32 fols. 22v-23r. 
in lance units, and then (11 December) eleven English captains, again in charge of single lance units. ${ }^{26}$ At the same time, however, the prominent English captain Richard Romsey continued in Florentine employ in charge of sixteen banners of cavalrymen, as did Thomas Corensie and John Aguillant, all of whom were hired in December 1367. ${ }^{27}$ Romsey continued to captain banner units into $1368 .^{28}$

The hires reflect a general military build-up in Florence that winter owing to the growing hostilities with Pisa and Milan and worries about the possible descent into Italy of the Holy Roman Emperor Charles IV. There was likewise civic discord in nearby San Miniato al Tedesco, a Florentine satellite on the border with Pisa. Florence continued to hire banner units, but the preeminence of the lance unit became clear. In 1368, captains of multilance units appear in Florentine service. The men were not only English, but also German, Italian, Burgundian and Gascon. Indeed, the Burgundians in Florentine employ appear to have been arrayed in lance units as early as the English, and just afterward. The largest lance unit in Florentine employ at the beginning of 1368 was a Burgundian one, led by Stefano di Santo Giovanni, who commanded 12 lances. ${ }^{29}$ Italian mercenaries, on the other hand, seem to have been slow in adopting the new unit, remaining mostly in banner contingents. ${ }^{30}$

The change to lances did not involve Hungarian cavalrymen at all. They became increasingly important to communal armies at this time. But unlike their German, Italian and English counterparts, Hungarian cavalrymen were also bowmen, who shot arrows from their mounts. They were arranged in their own units, usually consisting of twelve to fourteen men. It is unclear how the Hungarian units were integrated into the overall army.

The documents in the Florentine state archive trace a significant military buildup in in the spring and summer of 1368. The advent of Charles IV in Italy in May 1368 caused confusion and fear throughout northern and central Italy. When Charles entered Tuscany in September 1368, San Miniato rose up in rebellion against Florentine rule. ${ }^{31}$ In the meantime. Milanese

26 ASF, Scrivano di camera uscita, 32 fols. $23 \mathrm{v}-25 \mathrm{v}$

27 ASF, Scrivano di camera uscita, 32 fols. 30r-v

28 ASF, Scrivano di camera uscita, 36 fol. $23 \mathrm{r}$

29 ASF, Scrivano di camera uscita, 37 fols. 40r, 42r

30 ASF, Scrivano di camera uscita, 32 fols. 22r, 33v

31 STEFANI, M. di C. (1903): "Cronaca fiorentina". RIDOLICO, N. (ed.), Rerum Italicarum Scriptores, vol. 30, Part I. Città di Castello, S. Lapi, pp. 269-270. 
armies moved into Umbria by early 1369, trying to exploit unrest between Perugia and the papacy -the latter a long-time enemy of Milan..$^{32}$ The presence of Milan in Umbria frightened Florentine officials, who allied with Pope Urban V in November 1369.

As military conflict became inevitable. Florence's army continued to morph into a lance-based cavalry force. By 1369, all of its English cavalrymen were arranged in lance units, as were Breton, Gascon and German captains in communal service. Only ltalian captains remained in banner units. ${ }^{33}$ Oschino Archer now captained 12 lances. ${ }^{34}$ The Florentine politician Giovanni Corsi suggested that the city augment the army with "as many Englishmen as possible." ${ }^{35}$ To this end, Florence tried to recruit John Hawkwood, who was captain of the Milanese army. Hawkwood was not interested. The city tried to woo members of his army, but also with little success. ${ }^{36}$ The city hired instead more German, Gascon and Hungarian mercenaries. ${ }^{37}$

This "new" style Florentine army with its multinational collection of mercenaries engaged in battle with its Milanese counterpart near the town of Cascina (near Pisa) at the beginning of December 1369. The Florentine diarist Donato Velluti estimated that the Florentine army had approximately 3,000 horses and 3,000 infantrymen, including contingents sent by Pope Urban V. ${ }^{38}$ Velluti estimated that the opposing army had between 3,000 and 2,000 horses, while an anonymous Pisan chronicler put the number at 1,200 horses. ${ }^{39}$ Neither writer mentions whether the enemy cavalry was arrayed in lances, nor do they give any details about the infantry.

The Florentine force suffered a decisive defeat at Cascina. ${ }^{40}$ Velluti lamented that "almost all of our people" were taken, including the captain of war, Giovanni Malatacca, who was also wounded in the battle. ${ }^{41}$ Florence's

32 CAFERRO, John Hawkwood, pp. 136-137.

33 ASF, Scrivano di camera uscita, 38 fols. 17r-26r; Scrivano di camera uscita, 42 fols. 20r-37r

34 ASF, Camera del comune, camarlinghi uscita, 189 fol. 39r

35 ASF, Consulte e pratiche 10 fol $5 \mathrm{r}$

36 ASF, Scrivano di camera uscita, 44 fol. $21 \mathrm{r}$

37 ASF, Scrivano di camera uscita, 43 fol. $35 \mathrm{r}$

38 La cronica domestica di Messer Donato Velluti, edited by Isidoro del Lungo and Guglielmo Volpi Florence, 1914, p. 282.

39 "Chronica di Pisa," edited by L. A. Muratori, in Rerum Italicarum Scriptores, vol 15 (Milan, 1729), cols. 1055-1056.

40 CAFERRO, John Hawkwood, pp. 138-139.

41 La cronica domestica di Messer Donato Velluti, pp. 285-286. 
deployment of lances did not prove effective. It is in any case difficult to determine how the unit may have affected either side. The contemporary accounts of the battle of Cascina indicate that the Florentine army took the offensive, and Hawkwood a defensive stance. The most detailed account is that of Ranieri Sardo, a Pisan merchant, ambassador and government official, who may have stood closest to the action. According to Sardo, the Florentine army moved forward in good order, in three lines (schiere) toward Hawkwood's force, which had descended on foot and waited for them. The Florentine cavalry likewise dismounted from their horses and the initial battle took place on foot. ${ }^{42}$ Sardo makes no mention, however, of the presence of the lance units in either army -even if the dismounting technique may seem to serve as evidence of it. The Florentine accounts blame the captain Giovanni Malatacca for moving forward in poor order and getting drunk before the offensive to gain courage. According to Hawkwood's nineteenth century biographer, John Temple-Leader, the battle was precisely an example of the superior tactical skill of Hawkwood, who after dismounting his cavalry from their horses executed a flanking maneuver that succeeded in surrounding the enemy, whose mounts got stuck in the soft mud near the banks of the Arno River. ${ }^{43}$ The resemblance to Poitiers and English actions in France is palpable and suggests that the victory relied on English methods of which we may suppose that the lance formation was a component.

But Temple-Leader's romanticized account, which exalts the skill of his hero, does not correspond to the accounts of contemporary writers. Ranieri Sardo paints a far more chaotic scene, in which Hawkwood's army defended its position by tossing rocks from local fortifications at the heads of the Florentine horses to impede their advance. It was this action that caused the Florentine cavalry to dismount. Moreover, Hawkwood's great "flanking maneuver" is more implied than stated in Sardo's account which notes that the Florentine army had attempted a flanking maneuver first, with 800 cavalrymen, but failed placing the entire force in jeopardy.

Whatever the details at Cascina and the role of lance units, it is clear that the encounter increased Florence recourse to lances. Just after the defeat, Florentine officials rebuilt their army, hiring more lance units, now much

42 "Cronaca di Pisa di Ranieri Sardo" in Fonti per la Storia D'ltalia, edited by Ottavio Banti (Rome, 1963), pp. 193-195.

43 TEMPLE-LEADER, J. (1889): Sir John Hawkwood: Story of a Condottiere. London, Fisher Unwin, pp. 65-67. 
larger in size. The city recruited the German captains Oswald Buvolar and Konrad Chonz with 177 lances each, and Konrad Weitingen with 170 lances. ${ }^{44}$ Fortunately for the city, Hawkwood and his Milanese force unexpectedly retreated from Tuscany after the victory, looting the environs of Pisa as they rode back north to Lombardy. The next time Florence sent its army into the field, five years later during the War of Eight Saints against the pope, the cavalry consisted exclusively of lance units. ${ }^{45}$ But Florence, unlike after the battle of Cascina, relied mostly on small contingents, eschewing big units like those of Konrad Weitingen for fear of their effect on forces should they desert. ${ }^{46}$

\section{III}

The preeminence of the lance units reflects the influence of English soldiers in Italy in the middle of the fourteenth century. But the formation should not be taken as evidence of a heightened importance of cavalry in Florentine warfare during the period. Indeed, it is important to stress that infantry remained a critical part of communal armies. Their role needs to be underlined owing to the lack of attention they have received from modern scholars. This echoes in part the silences of contemporary chroniclers, who tend to stress the deeds of cavalrymen, the most conspicuous element of the army, while speaking in more general terms about the infantry. It is not uncommon for chronicles to give the precise names of cavalrymen, while at the same time referring to the infantry, invariably the largest part of the army, as a "mass of men." The tendency is based more on medieval class distinction than on overall importance to the army. Class distinctions were a fundamental part of medieval society.

And that infantry remained essential is clear from the undeniable fact that the most common type of engagement in which the Florentines were involved were sieges, for which infantrymen were the critical component. Violent encounters between knights on horseback occurred and drew the attention of contemporary writers. Sieges were usually tedious and it was dull. Indeed, any careful examination of contemporary sources shows that

44 ASF, Provvisioni registri, 57 fol. 166v; Scrivano di camera uscita, 44 fols. 30v-31v, $41 \mathrm{r}$, 167r-167v; Scrivano di camera uscita, 47 fols. $22 \mathrm{r}-32$.

45 CAFERRO, John Hawkwood, p. 169.

46 CAFERRO, "Continuity, Long-Term Service and Permanent Forces," pp. 29-33. 
the Florentines were very reluctant to engage in open battle. The risk was too great, as was the potential expense (in assembling a wholly new army). The wars of trecento ltaly were primarily wars of attrition in which enemies attempted to bleed opponents dry economically. Siege warfare also corresponded to the geography of Florence, protected to the north by Apennines in the Mugello and Casentino regions, and to the south by the Chianti hills. When Florence took on rural magnate families at the borders of the Romagna (a perennial enemy) the siege was the standard method of warfare. This was true also of war with Siena, Florence's great rival to the south. The bitter fighting between the two sides in 1390-92 was in the manner of a series of sieges to border towns. In such battles trebuchets and canons played a significant and still to be studied role. It is noteworthy that John Hawkwood, the greatest captain of the era, made his reputation for his victories in the field in the flat plains of Lombardy, which could accommodate prototypical pitched battles. But Hawkwood fought few such battles in Lombardy and when so engaged did not often fare well.

It is similarly important to stress that while Florentine forces evolved in the Fourteenth century, the continuities remained substantial. Whether in recruiting cavalrymen or infantrymen, Florence was steadfast in its practice of retaining effective soldiers in its employ over the long term, and building its army around a small cadre of such men. Florentine officials also hired soldiers from rural magnate clans, with familiar surnames such as Orsini, Farnese, Savelli -clans that appear just as frequently in thirteenth and fifteenth century documents. Enemy exiles also routinely found a place in Florentine armies. During Florence's war with Milan and Siena in 1392, city officials gave four prominent Sienese traitors -Orlando, Jacopo, and Naddo Malavolti and Bertoccio Tolomei- lifetime contracts for military service, permitting them to remain "as long as they wished." The most egregious instance of continuity is the great English captain John Hawkwood himself. Hawkwood was in great demand among all states, from the north to south of the peninsula. But it was ultimately Florence, by the late 1380s, who was able to keep him consistently in their employ, assuring their survival against the growing threat of Milan.

Finally, it is essential to view the Florentine army in terms of the frequent city leagues (taglie) of the era. Just as Daniel Waley noted for the late thirteenth and early fourteenth century, it is difficult to separate specifically Florentine army from those of the leagues that the city joined. The association required participating communes to pledge soldiers for a joint force. Unlike the earlier leagues, however, the ones of the mid and later trecento were often aimed at defense against marauding mercenary companies, in addition to hegemonic city states and rulers. Scholars have thus tended to view the 
leagues cynically, as ineffective in their stated aims and ultimately used by participants as a means of diplomacy aimed at manipulating and exploiting others. Giangaleazzo Visconti of Milan stands particularly accused of such deeds, using leagues as a veritable diplomatic weapon to isolate and weaken opponents. But the leagues were important to understanding civic armies. To quote Daniel Waley again, they reveal, like the earlier incarnation, a Florence army that was not entirely an expression of civic pride, but reflected also regional military priorities. The point is crucial because Florence joined many leagues in this period. The archival evidence shows that Florence participated taglie in 1336, 1344, 1347, 1349, 1351, 1354, $1356,1357,1358,1359,1361,1366,1369,1370,1371,1379,1380$, $1381,1384,1385,1389 / 90,1392,1396$ and 1398. The list is merely a guideline. The leagues were constantly being renegotiated and changed, so that it is difficult to know exactly where one ended and another began.

The leagues, like much of Florentine and Italian military history, require more study. But from the limited perspective of Florentine armies -the purpose of this essay- they meant that Florence continually had men at arms on the payroll and with that a species of standing army, albeit not strictly a civic one. When Florence fought Milan in 1351, its effort must be understood in terms of a league it made with Perugia and Siena for a joint army of 2,000 cavalrymen, for which Florence provided 1040 men, Perugia provided 575 men and Siena provided 375 men. The three cities also supplied 1000 crossbowmen, each according to the same proportion as the cavalrymen. ${ }^{47} \mathrm{After}$ the defeat of Florentine forces in 1369, the city immediately sought out an alliance and finally arranged one in October 1371 for a joint force of 2000 lances and 4,000 infantrymen (for four years) with the papacy, Pisa, Siena and Arezzo. ${ }^{48}$ The war with Milan was over, but Florence remained at arms, its force integrated with that of allies. The evidence not only makes clear the permanence of the Florence's army, but the deeply integrated nature of Italian military organization in trecento Italy.

\section{BIBLIOGRAPHY}

BAYLEY. C. C (1961): War and Society in Renaissance Florence: The De Militia of Leonardo Bruni. Toronto. University of Toronto Press.

BIANCHI, Silvana Anna (1995): "Gli eserciti delle signorie venete del Trecento fra continuità e trasformazione," in I/ Veneto nel medioevo, edited by Andrea Castagnetti and Gian Maria Varanini. Verona.

47 CANESTRINI: "Documenti," p. XVLIII-XLVIIX

48 Archivio di Stato di Siena (ASS), Capitoli 78 fols $1 \mathrm{r}-3 \mathrm{v}$ 
CANESTRINI, Giuseppe (1851): "Documenti per servire della milizia italiana del secolo XIII al XVI," Archivio Storico Italiano, ser. 1, 15.

CAFERRO, William (2006): John Hawkwood, An English Mercenary in Fourteenth Century ltaly Baltimore, Johns Hopkins Press.

CAFERRO, William (2008): "Continuity, Long-Term Service and Permanent Forces: A Reassessment of the Florentine Army in the Fourteenth Century." The Journal of Modern History 80, pp. 219-251.

CAFERRO, William (2008): "Warfare and Economy of Renaissance Italy, 1350-1450," Journal of Interdisciplinary History 39, pp. 167-209.

CAFERRO, William (2013): Edward Despenser, The Green Knight and the Lance Formation: Englishmen in Florentine Military Service," in The Hundred Years War, part III, edited by L. J. Andrew Villalon and Donald Kagay. Leiden. Brill, pp. 85-104.

CAFERRO, William (2013): Petrarch's War: Florentine Wages at the Time of the Black Death" Speculum 88.1 January, pp. 144-165.

CONTAMINE, Philippe (1980): War in the Middle Ages. Translated by Michael Jones. Oxford. Blackwell Publishing.

HALE, John (1986): War and Society in Renaissance Europe. Baltimore: Johns Hopkins Press.

GREEN, Louis (1986): Castruccio Castracani: A Study on the Origins of a Fourteenth-Century Italian Despotism. Oxford, University Press.

GRILLO, Paolo (2008): Cavalieri e popoli in armi: Le istitutioni military nell'Italia medievale. Bari. Editori Laterza.

MALLETT, Michael (1974): Mercenaries and their Masters. Totowa. New Jersey: Rowman and Littlefield.

Paoli, C. (1867): "Rendiconto e approvazioni di spese occorse nell'esercito fiorentino contro Pistoia nel Maggio 1302." Archivio Storico Italiano 6, pp. 3-16.

PIERI, Piero (1933): "Alcune questioni sopra fanterie in Italia nel periodo comunale." Rivista storica italiana, pp. 561-614.

PIERI, Piero (1952): Rinascimento e la crisi militare italiana. Turin. Einaudi. RICOTTI, Ercole (1844): Storia delle compagnie di ventura in Italia. Turin. Pomba.

SELZER, Stephan (2001): Deutsche Soldner im Italien des Trecento. Tubingen. Niemeyer.

WALEY, Daniel (1968): "The Army of the Florentine Republic from the Twelfth to the Fourteenth Century." In Florentine Studies, edited by Nicolai Rubinstein, 70-108. London. Faber and Faber. 